\title{
FIRST RECORD OF PROSTATIC SCHISTOSOMIASIS IN PERNAMBUCO, BRAZIL: SIGNS OF CHRONICITY IN
}

\section{AN ENDEMIC DISEASE}

Elainne Christine de Souza Gomes', Ana Lúcia Coutinho Domingues², Francisco Carlos Amanajás de Aguiar Júnior ${ }^{3}$, Katharine Raquel Pereira dos Santos ${ }^{3}$, Vitorina Nerivânia Covello Rehn ${ }^{3}$, Mariana Montenegro de Melo Lira $^{2}$ and Constança Simões Barbosa ${ }^{1}$

\section{ABSTRACT}

Schistosomiasis has affected the rural population of Pernambuco, Brazil, for centuries. The hepatosplenic and neurological manifestations of this parasitosis have often been described. However, prostatic schistosomiasis caused by Schistosoma mansoni had never been registered in Pernambuco, thus the importance of this particular case being reported. Case presentation: This report records the first case of prostatic schistosomiasis in Pernambuco. A 51-year-old patient underwent partial prostatectomy due to possible cancer and was diagnosed with this ectopic form of schistosomiasis. After the surgical procedure, stool samples were collected to run Kato-Katz parasitological tests, which were positive for S. mansoni, thus confirming that the patient was still infected. Laboratory blood tests and clinical examination showed alterations in liver function and confirmed the presence of hepatointestinal damage. Patient monitoring evidenced that the prostate-specific antigen levels remained high and, one year after the first surgical intervention, a new prostatic puncture showed that schistosomiasis and fibromatosis lesions remained present. It is noteworthy that after triple praziquantel treatment (April 2014, July 2014, February 2015) parasitological stool examinations were all negative for S. mansoni. In conclusion this accidental diagnosis of prostatic schistosomiasis raises doubts regarding the ability of healthcare services to identify and treat ectopic schistosomiasis. The persistently high levels of PSA even after surgical and pharmacological treatment, indicate irreversible damage to tissue caused by S. mansoni. Therefore, healthcare services need to be prepared to investigate and diagnose these cases, with a view to preventing chronic sequelae through early treatment.

KEY WORDS: Ectopic schistosomiasis; prostate cancer; Schistosoma mansoni

\footnotetext{
1. Schistosomiasis Laboratory and Reference Service, Department of Parasitology, Aggeu Magalhães Research Center, Fiocruz, Ministry of Health, Av. Professor Moraes Rego, s/n, CEP: 50740-465, Campus da UFPE, Cidade Universitária, Recife/PE, Brazil. 2. Clinical Hospital - Federal University of Pernambuco, Av. Prof. Moraes Rego, 1235, CEP: 50670-901, Cidade Universitária, Recife/PE - Brazil.

3. Vitória Academic Center, Federal University of Pernambuco. Rua Alto do Reservatório s/n CEP 55608-680, Bela Vista, Vitória de Santo Antão/PE, Brazil.
}

Corresponding author: Elainne Christine de Souza Gomes: E-mail: elainne.gomes@cpqam.fiocruz.br 


\section{RESUMO}

Primeiro registro de esquistossomose da próstata em Pernambuco, Brasil: a expressão da cronicidade de uma endemia

A esquistossomose acomete, há séculos, a população rural de Pernambuco. Manifestações hepatoesplênicas e neurológicas desta parasitose têm sido frequentemente descritas. No entanto, a esquistossomose da próstata, causada pelo Schistosoma mansoni, nunca havia sido reportada em Pernambuco, o que demonstra a necessidade de registrar este caso. Apresentação do caso: Um paciente de 51 anos, após realizar uma prostectomia parcial por suspeita de neoplasia, foi diagnosticado com esquistossomose da próstata. Após o procedimento cirúrgico, foram coletadas amostras de fezes para a realização de testes parasitológicos que se revelaram positivos para $S$. mansoni, confirmando que o paciente ainda estava infectado. Exames laboratoriais e clínicos mostraram alterações na função hepática e confirmaram danos hepatointestinais. O acompanhamento ambulatorial do paciente demonstrou que os níveis de antígeno prostático específico permaneceram elevados e, um ano após a primeira intervenção cirúrgica, um exame anatomopatológico mostrou a permanência de lesões fibromatosas esquistossomóticas. Vale ressaltar que, após três tratamentos com praziquantel (abril e julho/2014, fevereiro/2015), os exames de fezes apresentaram-se negativos para $S$. mansoni. Conclui-se que este diagnóstico acidental de esquistossomose da próstata levanta dúvidas sobre a capacidade dos serviços de saúde para identificar e tratar as formas ectópicas da esquistossomose. A manutenção dos elevados níveis de PSA, mesmo após tratamento cirúrgico e farmacológico, sugerem que os danos causados por S. mansoni aos tecidos são irreversíveis. Portanto, os serviços de saúde devem estar preparados para investigar e diagnosticar os casos, visando à prevenção de sequelas crônicas e ao tratamento precoce.

DESCRITORES: Esquistossomose ectópica; câncer de próstata; Schistosoma mansoni.

\section{INTRODUCTION}

Schistosomiasis mansoni is an endemic parasitic disease in all 43 municipalities of the Zona da Mata area of the state of Pernambuco, Brazil. It mainly affects rural populations that are exposed to the risk of infection on a daily basis, while performing their domestic, occupational and leisure activities alongside the rivers that cross the municipalities of this area. These rivers are perennial breeding sites for vector snails (Barbosa et al., 2006). For over two decades, schistosomiasis has been expanding in the coastal region of the state (Gomes et al., 2014), so that it has come to also affect urban populations, within a new transmission model for this disease that functions through accidental exposure to breeding sites of Biomphalaria during the rainy season, when floods occur in these locations (Gomes et al., 2012).

Despite the geographic expansion of the disease, the mortality rate and number of hospitalizations due to schistosomiasis have decreased in Pernambuco, in accordance with the national tendency. However, the number of cases recorded, in terms of the total number of hospitalizations $(5.8 \%$ per 10,000 admissions) is still high, which shows the severity of the problem in this State (Resendes et al., 2005). The results obtained in a parasitological survey among schoolchildren in all the municipalities of this area showed that the 
prevalence was over $30 \%$ in some municipalities, with a moderate parasite load of schistosomiasis (Barbosa et al., 2006).

Within this context, these locations continue to be responsible for the production of severe cases of schistosomiasis, in which ectopic forms of the disease have been gaining prominence over recent decades, with records of numerous cases of schistosomiasis myeloradiculopathy (Araújo et al., 2010). Although other ectopic forms such as prostatic schistosomiasis and seminal vesicle schistosomiasis are commonly recorded effects of Schistosoma haematobium infection (Schwartz et al, 2002), these are scarce when the etiological agent is Schistosoma mansoni, and to date only four cases have been reported in Brazilian scientific literature (Bacelar et al., 2007; Basilio-De-Oliveira et al., 2002; Lambertucci et al., 2006; Lopes et al., 2007). Therefore, the aim of the present study was to present the first record of prostatic schistosomiasis in the State of Pernambuco.

\section{CASE REPORT}

A 51-year-old patient with a history of abdominal pain and genitourinary complaints underwent ultrasonography which identified prostate enlargement. This was a suspected case of adenocarcinoma and the patient then underwent surgery comprising open prostatectomy with resection of the transition zone, in order to partially remove the prostate. A biopsy was positive for $S$. mansoni (December 2013). Subsequently, the patient went to the specialist schistosomiasis outpatient clinic at the Hospital das Clínicas de Pernambuco (February 2014), for clinical follow-up.

This patient was born in the municipality of Limoeiro, Pernambuco, a region that forms part of the Zona da Mata area of this state and is known to be endemic for schistosomiasis. During anamnesis, the patient mentioned that he had bathed in rivers until 1991.

From the physical examination, the patient was considered to be in a good general condition, weighing $66.5 \mathrm{Kg}$ and measuring $1.51 \mathrm{~cm}$, with body mass index (BMI) of 29.2 (i.e. overweight) and healthy skin color, without jaundice. He presented a distended abdomen $(+++/ 4)$, but neither his liver nor his spleen could be palpated and he did not have any edema. A parasitological stool test was conducted using the Kato-Katz method on three samples (February 2014), resulting that the patient was still infected with $S$. mansoni, with a parasite load of 184 eggs per gram of feces (live eggs), which suggested moderate intensity of infection. Biochemical and hematological laboratory blood tests (February 2014) showed liver function alterations (ALT $79 \mathrm{U} / \mathrm{L}$; gamma GT $348 \mathrm{U} / \mathrm{L}$; total cholesterol $224 \mathrm{mg} / \mathrm{dL})$, borderline triglycerides value $(175 \mathrm{mg} / \mathrm{dL})$ and slight eosinophilia consistent with the parasitosis $\left(8.4 \% ; 669 / \mathrm{mm}^{3}\right)$. Other routine blood tests proved normal.

Ultrasonography was performed to image the patient's abdomen in March 
2014, showing normal liver volume, with central periportal fibrosis (pattern D). The spleen was slightly enlarged: $13.0 \mathrm{~cm}$ longitudinally (normal: up to $12 \mathrm{~cm}$ ), $4.5 \mathrm{~cm}$ transversally and not visible below the left costal margin. These findings confirmed the presence of hepatointestinal damage in this patient.

From the first histopathological examination of the prostate, on the specimen collected from the patient in December 2013, the right lobe of the prostate macroscopically comprised three firm brownish segments weighing 190 grams altogether, where the largest segment measured $8.0 \times 8.0 \times 5.0 \mathrm{~cm}$. The left lobe of the prostate presented 12 firm brownish segments weighing 293 grams altogether, where the largest segment measured $9.0 \times 9.0 \times 7.0 \mathrm{~cm}$. Subsequently, histological sections of the material were examined under a microscope, and these revealed that the organ was of nodular formation, composed of stroma and hyperplastic glands. The alveolar parenchyma was composed of tubular glands with a few inactive alveoli. The glandular epithelium was predominantly pseudostratified with basal cells and typical secretory columnar cells. Eosinophilic prostatic concretions were observed in the lumen of the alveoli. Several chronic granulomatous foci were identified in the prostatic stroma (left and right lobe). These presented mononuclear infiltrate and variable intensity of eosinophilic epithelioid cells forming a palisade and a conspicuous giant foreign-body type cell on the periphery of the $S$. mansoni eggs (Figure 1A, 1B). Variable numbers of fibroblasts presenting concentric organization and tissue fibrosis were identified around the well-formed granulomata (Figure 2). From the anatomopathological examination of the prostate (left and right lobes), the diagnostic conclusion was chronic granulomatous schistosomiasis prostatitis, with a hyperplastic nodular prostate of stromal-glandular pattern, with no signs of malignancy.

Less than a year after the partial prostatectomy, the patient presented a progressive rise in prostate-specific antigen (PSA) levels: in August 2014, free PSA: $1.37 \mathrm{ng} / \mathrm{mL}$; total PSA: 9.38; and in November 2014, free PSA: $1.54 \mathrm{ng} /$ $\mathrm{mL}$; total PSA: 12.26. The reference levels are the following: free PSA: $<0.94 \mathrm{ng} /$ $\mathrm{mL}$; total PSA: $<4.0 \mathrm{ng} / \mathrm{mL}$. Based on these results, in February 2015, a prostate biopsy was performed to investigate tissue alterations relating to cancer and/or schistosomiasis. Macroscopic analysis on 25 fragments from the prostate gland (right and left base, right and left middle third, and left apex) showed filiform, elastic and brownish tissues. Histopathological examination under a microscope showed S. mansoni eggs on tissue from the right base of the prostate; and presence of areas of fibrosis with previous hemorrhage, on tissue from the right middle third of the prostate. There was no evidence of neoplasia in any fragment collected.

The patient was treated with praziquantel $50 \mathrm{mg} / \mathrm{kg}(600 \mathrm{mg} /$ tablet; 5.5 tablets) 3 times as it was the ectopic form of schistosomiasis (April 2014, July 2014 and February 2015). After treatment, three parasitological stool examinations with three different samples (performed in February 2015) by means of the KatoKatz method were carried out, and all the results were negative for S. mansoni. The patient is still under medical care. 

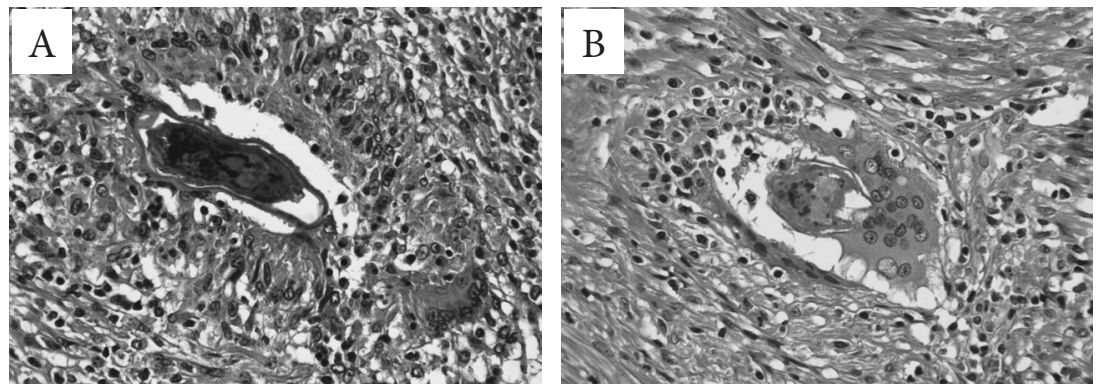

Figure 1. Histological section through the prostate, with $\mathrm{H} \& \mathrm{E}$ staining and final magnification 400x. [A] Schistosoma mansoni egg with preserved shell, pinkish cytoplasm, visible nuclei and an advanced stage of formation of miracidia. This is surrounded by granuloma consisting of epithelioid cells, chronic inflammatory infiltrate and mild fibrosis. Giant multinucleated cells and numerous eosinophils are present. [B] Giant multinucleated cell of foreign-body type and necrotic egg of S. mansoni with pyknotic nuclei and preserved shell, at the center of the granuloma.

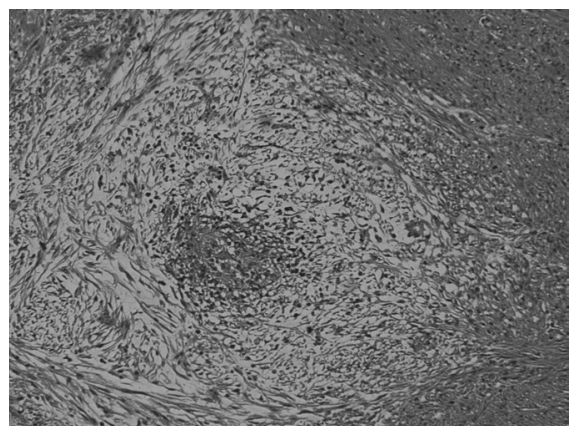

Figure 2. Histological section of the prostate, with H\&E staining and final magnification 100x. A characteristic granuloma can be seen surrounding a necrotic egg of Schistosoma mansoni. Granuloma characteristic of schistosomiasis, in prostate tissue.

\section{DISCUSSION}

Prostatic schistosomiasis has been linked to prostate cancer when the etiological agent is $S$. haematobium, which is responsible for schistosomiasis of the urinary tract, and this has often been reported in worldwide literature (Mazigo et al., 2010). However, in relation to the etiological agent S. mansoni, which inhabits the mesenteric veins that irrigate the intestine, this association is not well known. Only three concomitant cases of cancer and prostate schistosomiasis have been recorded in Brazil (Bacelar et al., 2007; Basilio-De-Oliveira et al., 2002; Lopes et al., 2007). However, despite the low frequency of reports regarding involvement of $S$. mansoni eggs in organs of the male reproductive system (only four reports in Brazilian literature), the first diagnosis was prostate cancer in all cases (Bacelar et al., 2007; Basilio-De-Oliveira et al., 2002; Lambertucci et al., 
2006; Lopes et al., 2007), thus corroborating the description of the present case, in which, although no prostate cancer was identified, this disease was the first diagnosis.

It is known that the severity and chronicity of schistosomiasis is directly related to liver and spleen damage (hepatosplenomegaly). However, ectopic forms of the disease have been gaining importance within the epidemiological scenario of this disease. This can be verified by the large number of schistosomotic myeloradiculopathy cases registered across Brazil, especially in the State of Pernambuco, where 139 cases of this clinical form have been recorded over the past 13 years (Araújo at al., 2010). The absence of prostatic schistosomiasis cases recorded in the State of Pernambuco exclude an epidemiological profile for this finding. Nevertheless, attention is drawn to certain factors within the epidemiological scenario of neoplasms: 1) the fact that Pernambuco shows the highest mortality rate for prostate cancer in northeastern Brazil (INCA, 2012); 2) a trend analysis on cancer mortality in State capitals and the non-metropolitan interior of Brazil, suggesting that rural municipalities in the northeastern region have rates that are at least twice as high as those observed in the State capitals, thus indicating the upward trend in the number of deaths caused by prostate cancer among men (Silva et al, 2011). Although this scenario does not allow any possible correlation to be noted in these studies, occurrences of cases of prostate cancer in patients from areas endemic for schistosomiasis should be targeted in further research, because of the possibility of the ectopic forms of this disease.

The histological findings in the present case, such as the presence of inflammation and granuloma tissue fibrosis due to the presence of $S$. mansoni eggs in prostatic tissue are expected for this type of immune response. These finding resembled those of many other reports in the literature (Bacelar et al., 2007; Lambertucci et al., 2006; Mazigo et al., 2010). The clinical manifestations of $S$. mansoni infection of the prostate presented features similar to those of prostatic adenocarcinoma, such as pollakiuria and nocturia, weak urinary stream, impotence, pain during urination and weakness in the legs and feet.

The use of three doses of praziquantel to treat ectopic forms is a clinical practice used by many specialists to ensure parasitological cure in cases of ectopic forms, given that: a) the cure with only 1 dose is around $75 \%$ (Zwang \& Olliaro, 2014); b) in ectopic forms the worm eggs are encysted (encapsulated by granumolas), hindering drug access.

\section{CONCLUSION}

The accidental diagnosing of this case of prostatic schistosomiasis and lack of treatment even after its confirmation through histopathological examination demonstrates the inability of the healthcare services to detect cases of ectopic schistosomiasis in patients from endemic areas. It also shows that severe forms of schistosomiasis are recurrent and this endemic disease is far from being controlled. The high levels of PSA and the residual tissue damage 
caused by $S$. mansoni after surgical and pharmacological treatment demonstrate that tissue damage seems to be irreversible, once tissue recovery is expected to occur 4 weeks after treatment. Therefore, healthcare services need to be prepared to investigate and diagnose these cases in an effective manner, with a view to preventing chronic sequelae.

The diagnosing of this case brings to the fore issues regarding the efficiency of the flow of medical care within the Brazilian health system, given that this patient came to the healthcare services seeking high-complexity assistance. It is hoped that this paper will draw attention to this other form of neglect regarding diagnosis and treatment of schistosomiasis in Brazil and worldwide.

\section{REFERENCES}

1. Araújo KC, Rosa e Silva C, Santos AGA, Barbosa CS, Ferrari TCA. Clinical-epidemiologic profile of the schistosomal myeloradiculopathy in Pernambuco, Brazil. Mem Inst Oswaldo Cruz 105: 454459, 2010.

2. Bacelar A, Castro LGM, Queiroz AC, Cafe E. Association Bewteen Prostate Cancer and Schistosomiasis inYoung Patients: Case report and Literature Review. Bras J Infect Dis 11: 520, 2007.

3. Barbosa CS, Favre TC, Wanderley TN, Callou AC, Pieri OS. Assessment of schistosomiasis, through school surveys, in the Forest Zone of Pernambuco, Brazil. Mem Inst Oswaldo Cruz 101: 55-62, 2006.

4. Basilio-De-Oliveira CA, Aquino A, Simon EF, Eyer-Silva WA. Concomitant prostatic schistosomiasis and adenocarcinoma: case report and review. Braz J Infect Dis 6: 45-49, 2002.

5. Gomes ECS, Leal Neto OB, Oliveira FJ, Campos JV, Souza-Santos R, Barbosa CS. Risk analysis for occurrences of schistosomiasis in the coastal area of Porto de Galinhas, Pernambuco, Brazil. BMC Infect Dis 14: 101, 2014.

6. Gomes ECS, Leal Neto OB, Albuquerque J, Silva HP, Barbosa CS. Schistosomiasis transmission and environmental change: a spatio-temporal analysis in Porto de Galinhas, Pernambuco - Brazil. Int J Health Geogr 11: 5, 2012.

7. Instituto Nacional do Câncer (INCA). Atlas on-line de mortalidade, 2012. Disponível em: https:// mortalidade.inca.gov.br/MortalidadeWeb/. Acessado em 27.11.2014.

8. Lambertucci JR, Voieta I, Barbosa AJA. Schistosomiasis mansoni of the prostate. Rev Soc Bras Med Trop 39: 233-234, 2006.

9. Lopes EJA, Almeida CER, Jacobino M. Esquistossomose mansônica em vesícula seminal. Rev Soc Bras Med Trop 40: 341-342, 2007.

10. Mazigo HD, Zinga M, Heukelbach J, Rambau P. Case Series of Adenocarcinoma of the Prostate Associated with Schistosoma haematobium Infection in Tanzania. J Glob Infect Dis 2: 307-309, 2010.

11. Resendes APC, Souza-Santos R, Barbosa CS. Internação e Mortalidade por esquistossomose mansônica no Estado de Pernambuco, Brasil, 1992/2000. Cad Saude Publica 21: 1392-1400, 2005.

12. Schwartz E, Pick N, Shazberg G, Potasman I. Hematospermia Due to Schistosome Infection in Travelers: Diagnostic and Treatment Challenges. Clin Infect Dis 35: 1420-1424, 2002.

13. Silva GA, Gamarra CJ, Girianelli VR, Valente JG. Tendência da mortalidade por câncer nas capitais e interior do Brasil entre 1980 e 2006. Rev Saúde Pública 45: 1009-1018, 2011.

14. Zwang J, Olliaro PL. Clinical efficacy and tolerability of praziquantel for intestinal and urinary schistosomiasis-a meta-analysis of comparative and non-comparative clinical trials. PLoS Negl Trop Dis. 8: e3286, 2014. 